\title{
Inhibitory effects of Euphorbia tirucalli latex on murine B16/F10 melanoma cells and lung metastasis
}

\author{
RAFAEL LANCIANI BRUNETTI $^{1 *}$, DIEGO PINHA ALVES DA PAZ ${ }^{1 *}$, \\ IVONE IZABEL MACKOWIAK DA FONSECA ${ }^{1}$, MÁRCIA KAZUMI NAGAMINE ${ }^{1}$, \\ CLAUDIA MADALENA CABRERA MORI ${ }^{1}$, MURILO PENTEADO DEL GRANDE ${ }^{1}$, \\ NICOLLE QUEIROZ-HAZARBASSANOV ${ }^{1}$, CRISTINA OLIVEIRA MASSOCO SALLES-GOMES ${ }^{1}$, \\ MARIA LUCIA ZAIDAN DAGLI ${ }^{1}$ and FRANCISCO JAVIER HERNANDEZ-BLAZQUEZ ${ }^{2}$ \\ Departments of ${ }^{1}$ Pathology and ${ }^{2}$ Surgery, School of Veterinary Medicine and Animal Science, \\ University of São Paulo, São Paulo 05508-900, Brazil
}

Received November 13, 2018; Accepted March 13, 2019

DOI: $10.3892 / \mathrm{mco} .2019 .1916$

\begin{abstract}
Euphorbia tirucalli (E. tirucalli) is a tropical and subtropical plant that produces a latex which is used for several purposes. The components of $E$. tirucalli latex include triterpenes, diterpenes and steroids. The aim of the present study was to evaluate the effects of diluted E. tirucalli latex on murine B16/F10 melanoma cells and lung metastasis. For this purpose, an in vitro study was first performed, in which B16/F10 cells were treated with diluted $(1 / 2$ to $1 / 11,192)$ E. tirucalli latex. In a second study, B16/F10 melanoma cells were inoculated into the tail vein of mice to generate lung metastases; the mice then received $0.467 \mu \mathrm{g}$ of latex diluted in $200 \mathrm{ml}$ saline by gavage for 14 days. A significant decrease in B16/F10 cell viability was observed using the MTT assay at 24 and $48 \mathrm{~h}$ after treatment with E. tirucalli latex. In addition, a significant decrease in the volume fraction occupied by B16/F10 metastatic colonies in the lungs was observed in mice treated with $E$. tirucalli latex. These results confirm the antineoplastic effects of diluted E. tirucalli latex.
\end{abstract}

\section{Introduction}

Euphorbia tirucalli (E. tirucalli), commonly referred to as 'aveloz', is a tropical and subtropical ornamental plant, traditionally used in folk medicine for the treatment of syphilis,

Correspondence to: Dr Maria Lucia Zaidan Dagli, Department of Pathology, School of Veterinary Medicine and Animal Science, University of São Paulo, 87 Av. Prof. Dr. Orlando Marques de Paiva, São Paulo 05508-900, Brazil

E-mail:mlzdagli@usp.br

*Contributed equally

Key words: melanoma, Euphorbia tirucalli, metastases, medicinal plants asthma, rheumatism, arthritis (1) and cancer (2-7). This plant most likely originated from tropical East Africa, and is reportedly endemic in a number of African countries; it may also be found in southern Europe, Asia and the Americas, where it is used for decorative as well as medicinal purposes (8). E. tirucalli is widely cultivated in Brazil, particularly in the north and northeast regions (9).

E. tirucalli produces a latex that is a vesicant and is commonly used as a remedy against several diseases. However, most of its medicinal properties are reported informally and there appears to be little scientific evidence to validate them (8). The main substances present in E. tirucalli latex are cyclotirucanenol (triterpene), diterpene ester, steroids and tirucalicine (diterpene) (8). Its active components include euphol, euphorbol, euphorone, isoeuphoral, taraxasterol, tirucalol, citric acid, glucose, kamepferol, malic acid, sapogenin acetate and succinic acid $(10,11)$. Recently, Palharini et al (12) investigated eutirucallin, a lectin with antitumor and antimicrobial properties. Some of these active components have been reported to have biological activities, such as preventive anticancer activity, antitumor, antimutagenic, antibacterial, laxative, antiseptic, disinfectant, anti-inflammatory, antistreptococcal, antiparasitic, antiulcer, analgesic, antiasthmatic and expectorant properties, as well as anticancer effects against specific types of cancer of the breast, lung, cervix, esophagus and mouth (13).

Valadares et al (5) first reported that the extract of E. tirucalli modulated myelopoiesis and reduced the growth of mouse Ehrlich ascites tumor. Wang et al (14) demonstrated that euphol inhibited the growth of T74D human breast cancer cells and reduced the levels of cyclin A and B1 expression, which corresponded to the decreased distribution of cells in the $\mathrm{S}$ and G2/M phases, respectively. These results indicated that euphol is an active ingredient of E. tirucalli that exerts anticancer effects, possibly by arresting cell cycle progression of cancer cells. Santos et al (13) also demonstrated that E. tirucalli extract inhibited the growth of Ehrlich ascites tumor. Furthermore, euphol inhibited the growth of human gastric cancer cells by modulating apoptosis mediated by ERK $1 / 2$ and cyclin D1 (7). 
The aim of the present study was to investigate the in vitro and in vivo effects of diluted E. tirucalli latex on B16/F10 melanoma cells.

\section{Materials and methods}

E. tirucalli latex. Euphorbia tirucalli Lineu (Euphorbiaceae) was obtained from the plant resource center Sabor da Fazenda (São Paulo, Brazil) and was certified by the ECOCERT body (http://www.brazil.ecocert.com/index/). In addition, a sample of pressed plant was obtained, dried in an oven, fixed on a standard-size paperboard accompanied by a label containing information on the plant and the collection site, and stored in the herbarium of the Department of Botany of the Institute of Biosciences of the University of São Paulo, Brazil (http://www. ib.usp.br/en/botany-welcome.html).

All the E. tirucalli latex required for the experiment was collected directly from the stems; latex drops were collected from the plant stem in a sterilized glass beaker.

Dilution of E. tirucalli latex in saline solution was performed according to its popular use, namely 9 drops $(0.0934 \mathrm{~g})$ in 1 liter of saline solution. A total of $5 \mu \mathrm{l}$ of this solution, containing $0.467 \mu \mathrm{g}$ of E. tirucalli latex (for an animal weighing $25 \mathrm{~g}$ ) was transferred to $200 \mu \mathrm{l}$ (q.s.) and this volume was administered to each mouse. This quantity of latex is equivalent to that recommended in popular medicine for a person weighing $70 \mathrm{~kg}(1.3 \mathrm{~g})$.

Immediately after the preparation, the diluted latex saline solution of E. tirucalli and the control saline solution were stored at $4^{\circ} \mathrm{C}$.

Culture of B16/F10 cells. B16/F10 murine melanoma cells were cultured with Dulbecco's modified Eagle's medium (DMEM) supplemented with $10 \%$ fetal bovine serum, penicillin $(50 \mathrm{IU} / \mathrm{ml})$, streptomycin $(50 \mathrm{mg} / \mathrm{ml})$ and L-glutamine ( $2 \mathrm{mmol} / \mathrm{l})$. The bottles were kept in a humidified incubator at $37^{\circ} \mathrm{C}$ in an atmosphere of 5\% CO2 and $95 \%$ air under temperature-controlled conditions.

\section{In vitro experiment}

Evaluation of cell proliferation with the MTT assay. On day 1, B16/F10 murine melanoma cells were plated on three flat-bottomed 96-well plates at a density of $3 \times 10^{3}$ cells/well (150 $\mu \mathrm{l}$ of DMEM/well). DMEM was supplemented with fetal bovine serum, penicillin $(50 \mathrm{IU} / \mathrm{ml})$, streptomycin $(50 \mathrm{mg} / \mathrm{ml})$ and L-glutamine $(2 \mathrm{mmol} / \mathrm{l})$. A stock solution of latex in DMEM at a concentration of $0.1037 \mu \mathrm{g} / \mu 1$ was prepared. Serial dilutions were prepared using DMEM (1/2, $1 / 4,1 / 8,1 / 16,1 / 32,1 / 64,1 / 128,1 / 256,1 / 512,1 / 1,024,1 / 2,048$, $1 / 5,096$ and $1 / 11,192)$. On day $2,100 \mu \mathrm{l} /$ well of each dilution of the stock solution was added to each well. The amount of latex per dilution is shown in Table I. The control group was treated with $100 \mu \mathrm{l} /$ well DMEM.

After 24, 48 and $72 \mathrm{~h}, 10 \mu \mathrm{l}$ tetrazolium 3-(4,5-dimethylthiazol-2-yl)-2,5-diphenyl tetrazolium bromide (MTT; Amresco, LLC, Solon, OH, USA) was added to both the control and experimental wells. The salt was added to each well of the plates to be metabolized by viable cells, and incubated for $3 \mathrm{~h}$ in a humidified chamber at $37^{\circ} \mathrm{C}$ in an atmosphere of $5 \% \mathrm{CO}_{2}$ and $95 \%$ air under temperature-controlled conditions.
Table I. Amount of latex corresponding to each dilution present in each well of the $250-\mu 1$ plate.

\begin{tabular}{lcc}
\hline Dilution & $\begin{array}{c}\text { Latex amount }(\mu \mathrm{g}) \\
\text { per well }\end{array}$ & $\begin{array}{c}\text { Latex concentration } \\
(\mathrm{ng} / \mu \mathrm{l}) \text { per well }\end{array}$ \\
\hline $1 / 2$ & 5.185 & 82.96 \\
$1 / 4$ & 2.5925 & 41.48 \\
$1 / 8$ & 1.2962 & 20.74 \\
$1 / 16$ & 0.6481 & 10.37 \\
$1 / 32$ & 0.3240 & 5.185 \\
$1 / 64$ & 0.1620 & 2.5925 \\
$1 / 128$ & 0.0810 & 1.29625 \\
$1 / 256$ & 0.0405 & 0.648125 \\
$1 / 512$ & 0.0202 & 0.324063 \\
$1 / 1,024$ & 0.0101 & 0.162031 \\
$1 / 2,048$ & 0.0051 & 0.081016 \\
$1 / 5,096$ & 0.0025 & 0.040508 \\
$1 / 11,192$ & 0.0013 & 0.020254 \\
\hline
\end{tabular}

Subsequently, the cells were centrifuged at 2,755 x $\mathrm{g}$ for $10 \mathrm{~min}$, and the supernatant was discarded. The formazan crystals were dissolved with $100 \mu \mathrm{l} /$ well DMSO. The reading was performed in a Multiskan EX (Thermo Fisher Scientific, Inc., Waltham, MA, USA) ELISA reader at $570 \mathrm{~nm}$. The experiments were carried out in six replicates.

\section{In vivo experiment}

Experimental animals. A total of 14 C57BL/6 male mice, aged 2 months and weighing 25-30 g, were used in the experiments. The mice were obtained from the Animal Facility of the Department of Pathology of the School of Veterinary Medicine and Animal Science of the University of São Paulo and were kept under the following environmental conditions: 12 -h light/dark cycle, temperature $22 \pm 2^{\circ} \mathrm{C}$ and relative humidity $45-65 \%$. During the experimental period, the animals remained in the animal facility, and had access to water and balanced feed ad libitum. The experimental protocols were approved by the Committee on Ethics in Animal Use (CEUA) of the School of Veterinary Medicine and animal Science of the University of São Paulo (SVMAS-USP, process no. 3410250216) and the School of Medicine of the University of São Paulo (FM-USP, process no. 043/16).

Inoculation of B16/F10 melanoma cells into the tail vein for the development of lung metastasis in mice. Cell suspensions containing murine melanoma B16/F10 cells (100 $\mu$ l containing $5 \times 10^{5}$ cells/animal) were inoculated into the tail vein of 6-month-old C57BL/6 male mice (15-17). The animals were treated with E. tirucalli latex daily by gavage $(0.467 \mu \mathrm{g} / 25 \mathrm{~g}$ in $200 \mu \mathrm{l}$ ), diluted as 9 drops of latex in 1 liter of saline solution, or saline solution for 14 days (control), starting 1 week after inoculation. At the end of the experiment, the animals were euthanized with an overdose of intraperitoneal ketamine and xylazine solution (doses $>100 \mathrm{mg} / \mathrm{kg}$ ketamine and $10 \mathrm{mg} / \mathrm{kg}$ xylazine were used), and death was confirmed by verifying the lack of respiratory, cardiac and nervous functions. The lungs 


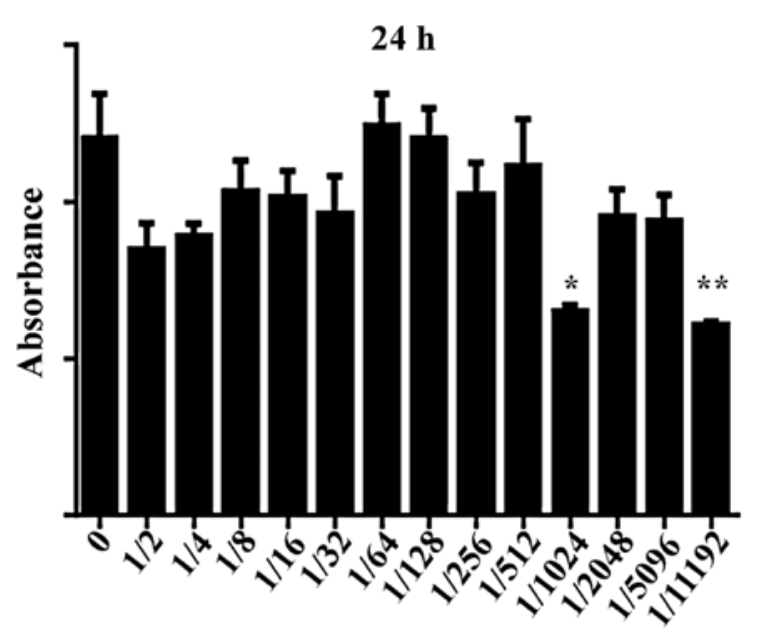

E. tirucalli latex serial dilution

Figure 1. Cell viability analysis by the MTT method after $24 \mathrm{~h}$ of treatment with different dilutions of $E$. tirucalli latex. Decreased cell viability was observed at serial dilutions of $1 / 1,024$ and 1/11,192. Column 0 represents only melanoma cells. The Kruskall-Wallis statistical test was used to compare the results. $\mathrm{N}=6$ replicates; ${ }^{*} \mathrm{P}<0.05$ and ${ }^{* * *} \mathrm{P}<0.01$. E. tirucalli, Euphorbia tirucalli.

were removed and fixed in buffered formalin solution (10\%) for histopathological and morphometric examination. Representative samples of the lungs, liver, kidneys and spleen were fixed in $10 \%$ formalin, embedded in paraffin wax and the $5-\mu \mathrm{m}$ histological sections were routinely processed and stained with hematoxylin and eosin (H\&E) for histopathological analysis.

Quantification of the volumetric fraction of lungs occupied by metastatic melanoma. The volumetric fraction occupied by the lung colonies of the melanoma group and the E. tirucalli latex-treated melanoma group was calculated by the dot-counting method (18). The lungs were fixed in $10 \%$ formalin and embedded in paraffin. A total of 15 non-consecutive, randomly selected histological sections of the lungs of each animal ( 7 animals from the melanoma group and 7 animals from the E. tirucalli latex-treated melanoma group) were prepared.

The histological slides were photographed under the Leica M165C stereo microscope (Leica Microsystems, Inc.), using the image capture system composed by the Leica DFC 290 camera and the LAS V4.1 program in the Laboratory of Stochastic Stereology and Chemical Anatomy (LSSCA-USP). Next, the images covering the whole area of the histological section were superimposed by a grid of points where all the points that covered the lung section were counted, and the points that covered only the pulmonary melanoma metastases were registered. The process was repeated 5 times for each image by rotating the grid. The percentage of points that coincided with the metastases in all sections was calculated in relation to the total number of points that coincided with the lung section, and it corresponded to the proportion of volume occupied by the nodules in relation to the total lung tissue.

Statistical analysis. To compare cell viability in cell cultures treated with E. tirucalli latex, the Kruskall-Wallis statistical test was used. Subsequent comparisons were performed by

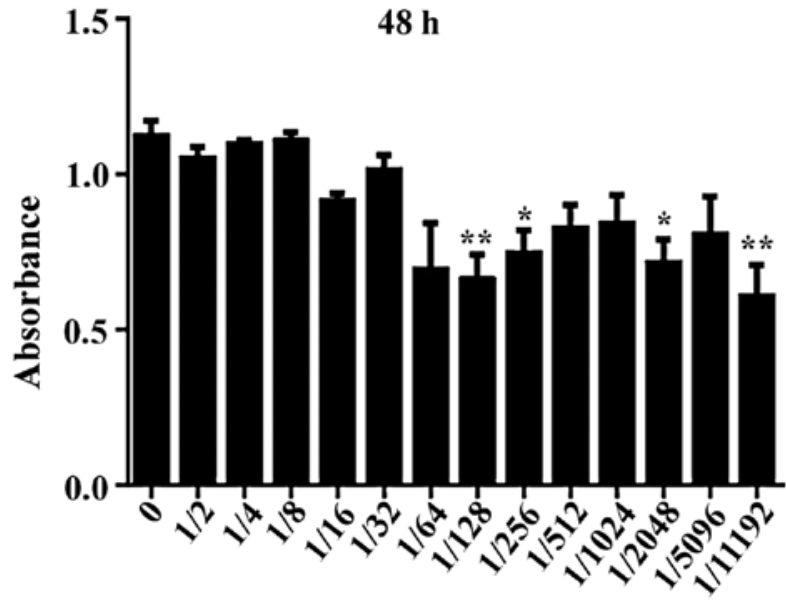

\section{E. tirucalli latex serial dilution}

Figure 2. Cell viability analysis by the MTT method after $48 \mathrm{~h}$ of treatment with different dilutions of E. tirucalli latex. Decreased cell viability was observed at serial dilutions of $1 / 128,1 / 256,1 / 2,048$ and 1/11,192. Column 0 represents only melanoma cells. The Kruskall-Wallis statistical test was used to compare the obtained results. $\mathrm{N}=6$ replicates; ${ }^{*} \mathrm{P}<0.05$ and ${ }^{* *} \mathrm{P}<0.01$. E. tirucalli, Euphorbia tirucalli.

the Dunn's post hoc test. To evaluate the volumetric fraction of lungs occupied by metastatic melanoma, the Student's $\mathrm{t}$-test was applied, and data are expressed as mean \pm standard deviation. Both the statistical tests and the assembly of the graphs and tables were performed with Prism 6 software (GraphPad Software, Inc., La Jolla, CA, USA) and GraphPad InStat version 3.10. P-values $<0.05$ were considered to indicate statistically significant differences.

\section{Results}

Evaluation of cell viability following treatment of murine B16/F10 melanoma cells with E. tirucalli latex. To investigate the effect of $E$. tirucalli latex treatment on murine B16/F10 melanoma cells, different dilutions $(1 / 2,1 / 4,1 / 8,1 / 16,1 / 32$, $1 / 64,1 / 128,1 / 256,1 / 512,1 / 1,024,1 / 2,048,1 / 5,096$ and 1/11,192) were used. The cell viability was evaluated by the MTT assay at 24, 48 and $72 \mathrm{~h}$.

In this series of experiments, cell incubation at different dilutions of E. tirucalli for $24 \mathrm{~h}$ reduced cell viability at the dilutions of 1/1,024 (46.58\%) and 1/11,192 (52.67\%) $(\mathrm{P}<0.05$; Fig. 1).

Incubation of the cells with different dilutions of $E$. tirucalli for $48 \mathrm{~h}$ reduced cell viability at the dilutions of $1 / 128$ (47.67\%), 1/256 (41.83\%), 1/2,048 (43.17\%) and at 1/11,192 (49.83\%) $(\mathrm{P}<0.0001$; Fig. 2).

However, incubation with different dilutions of E. tirucalli latex for $72 \mathrm{~h}$ did not significantly reduce cell viability any further ( $\mathrm{P}>0.05$; Fig. 3 ).

Evaluation of the effects of E. tirucalli treatment on the development of B16/F10 melanoma metastasis. For this experiment, it was examined whether treatment with E. tirucalli could also reduce the number of lung metastases. A total of $100 \mu \mathrm{l}$ of B16/F10 murine melanoma cell suspension were inoculated into the tail vein of $\mathrm{C} 57 \mathrm{BL} / 6$ mice $\left(5 \times 10^{5}\right.$ cells/animal).

After 14 days of treatment with E. tirucalli, all mice were euthanized and necropsies were performed. Macroscopically, 
Table II. Volume fraction of lung occupied by B16/F10 melanoma metastatic colonies in E. tirucalli latex-treated or untreated C57B16 mice.

\begin{tabular}{lcc}
\hline Groups & $\begin{array}{c}\text { Number } \\
\text { of animals }\end{array}$ & Mean (\%) \pm SD \\
\hline Untreated mice & 7 & $65.7 \pm 15.4$ \\
$\begin{array}{l}\text { E.tirucalli-treated mice } \\
\text { P-value }^{\text {a }}\end{array}$ & 7 & $13.8 \pm 7.5$ \\
\hline
\end{tabular}

${ }^{a}$ Mann-Whitney U test. SD, standard deviation.

the lungs of the control group had numerous melanoma nodules, whereas the lungs of the mice treated with E. tirucalli exhibited markedly smaller numbers of metastatic nodules (Fig. 4).

Quantification of the volumetric fraction occupied by metastatic melanoma. The results of the quantification of the volumetric fraction occupied by metastatic melanoma foci in E. tirucalli latex-treated (MT) or -untreated (M) C57B16 mouse lungs are summarized in Table II. While in control mice $35 \pm 18 \%$ of the lungs were occupied by melanoma, only $10.5 \pm 7.7 \%$ of the lung area was occupied by melanoma in E. tirucalli-treated mice. The difference was statistically significant (Student's t-test, $\mathrm{P}=0.024$; Figs. 5 and 6).

Histopathological analysis. No microscopic alterations were observed in the histological sections of the liver, kidneys and spleen of mice treated with diluted E. tirucalli latex; in the lungs, small areas of congestion and hemorrhage were observed (control group). These results indicate that the E. tirucalli latex does not cause toxicity to mice at the abovementioned dilutions.

\section{Discussion}

Treatment modalities popular in folk medicine, mostly medicinal plants, may be of therapeutic value in a number of diseases. However, they must be approached with caution and thoroughly investigated in order to objectively evaluate their efficacy and safety (19).

The objective of the present study was to scientifically evaluate the effects of $E$. tirucalli latex on B16/F10 murine melanoma cells in vitro and in vivo. Only little information is currently available in the literature on E. tirucalli latex and, to the best of our knowledge, this is the first such study on melanoma, a highly lethal cancer affecting humans and animals.

In the in vitro experiment, it was observed that $E$. tirucalli latex significantly reduced the viability of B16/F10 murine melanoma cells at high dilutions. Silva et al (20) demonstrated that euphol, a major component of E. tirucalli latex, exerted cytotoxic effects on several human cell lines.

In fact, dilutions of E. tirucalli latex were effective in reducing melanoma cell viability (as detected by MTT assay) after 24 and $48 \mathrm{~h}$ of treatment, but not after $72 \mathrm{~h}$. In addition, the higher dilutions of E. tirucalli were consistently more effective in reducing the viability of tumor cells. These findings indicate

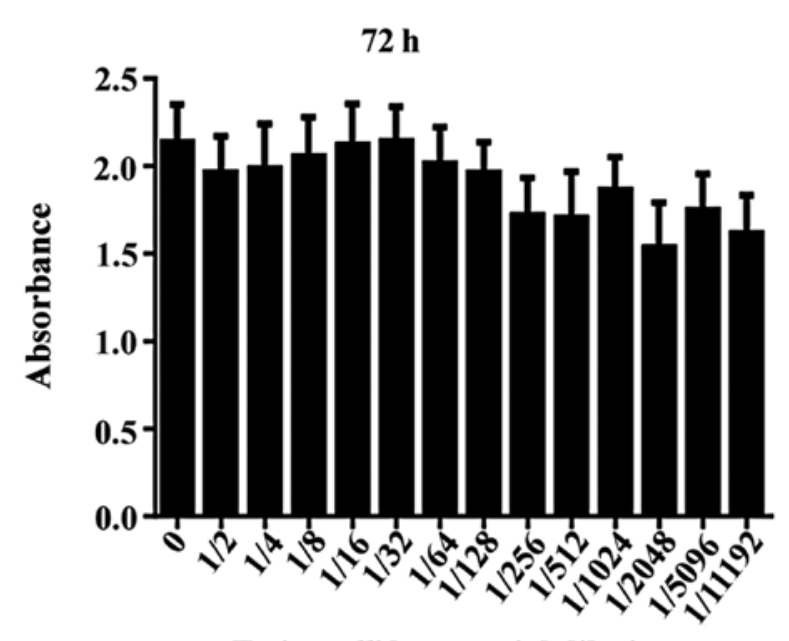

\section{E. tirucalli latex serial dilution}

Figure 3. Cell viability analysis by the MTT method revealed no significant decrease in cell viability in any of the serial dilutions after $72 \mathrm{~h}$ of treatment with E. tirucalli latex. Column 0 represents only melanoma cells. The Kruskall-Wallis statistical test used to compare the obtained results. $\mathrm{N}=6$ replicates. E. tirucalli, Euphorbia tirucalli.

that the effectiveness of E. tirucalli latex against melanoma cells was time-dependent (therefore, it must be administered daily or every other day in order to be effective), and its action apparently occurs at low doses, or possibly at doses that effectively reach the tumor cells inside the tumor mass when the diluted plant latex is administered orally. However, this hormetic effect must be further investigated.

Although in vitro studies are informative, when isolated, they cannot predict the in vivo efficacy of new therapies. These must be tested either in laboratory animals, or, optimally, in well-conducted clinical trials. In the present study, an in vivo experiment was conducted to confirm the efficacy of the in vitro results.

Metastasis is characteristic of malignant tumors, and is considered as the main cause of death among cancer patients. Therefore, we investigated the effectiveness of E. tirucalli latex in controlling metastasis in mice. Spontaneous metastasis mouse models are rare; therefore, in the present study, mice were inoculated with tumor cells through the tail vein to generate lung metastases (15-17) in order to evaluate the possible effect of E. tirucalli latex on metastatic growth. It was observed that the 14-day treatment with diluted E. tirucalli latex significantly reduced the volume fraction of the mouse lungs occupied by metastatic melanoma nodules, indicating that it is important to further evaluate the effect of this popular dilution of E. tirucalli on other tumors and in the context of other treatment protocols.

Furthermore, when the vital organs of the mice were microscopically examined, it was verified that E. tirucalli latex, at the popularly used dilution of 9 drops in 1 liter of saline solution, was not associated with adverse histopathological changes in the liver, kidneys or spleen. The absence of histopathological alterations indicates lack of toxicity of E. tirucalli at the commonly used dilution.

The experiments performed using B16/F10 melanoma cells (in vitro and metastasis assays) revealed consistent antineoplastic effects, confirming the efficacy of E. tirucalli 

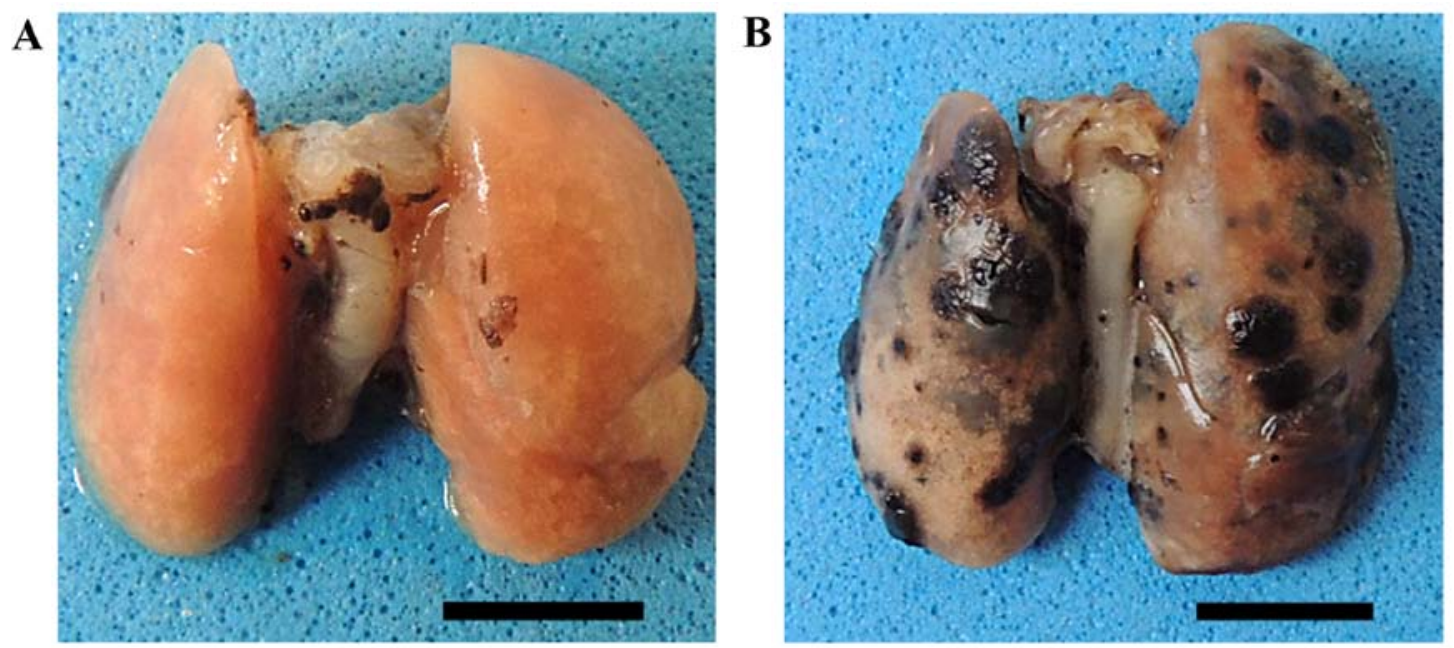

Figure 4. Macroscopic examination of the lungs of C57BL/6 mice that received tail vein injection of B16/F10 melanoma cells. (A) In the E. tirucalli-treated group, melanoma cell colonies were observed, but they were smaller and fewer compared with the (B) control group, which received no E. tirucalli. Bar, 10 mm.

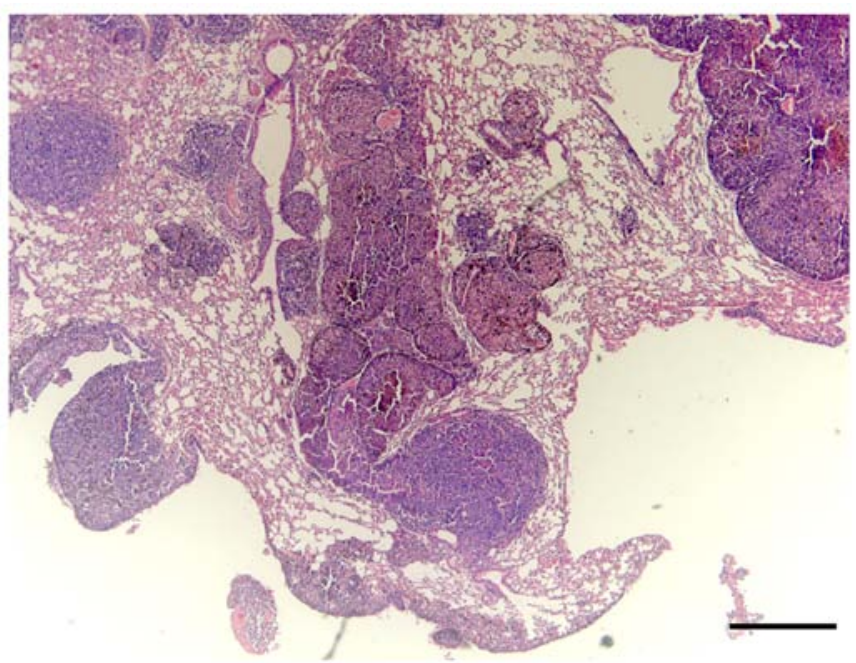

Figure 5. Photomicrograph of a histological section from the lung of a C57BL/6 mouse that was inoculated through the tail vein with B16/F10 melanoma cells. The presence of melanoma cell colonies in the pulmonary parenchyma is observed. Control group. Hematoxylin and eosin staining. Bar, $500 \mu \mathrm{m}$.

latex against B16/F10 murine melanoma. These anticancer effects are most likely associated with euphol $(7,14)$ and/or eutirucallin (12). However, the exact mechanisms underlying the effects of diluted E. tirucalli latex require further investigation.

In conclusion, the goal of any experimental study is to test hypotheses which, if scientifically proven, may be used to improve the quality of life and the survival of patients. In the present study, E. tirucalli latex has shown promising antineoplastic properties that warrant further validation in clinical trials.

\section{Acknowledgements}

This study is part of the Master's Dissertation of Rafael Lanciani Brunetti at the Graduate Program on Experimental Physiopathology of the School of Medicine of the University

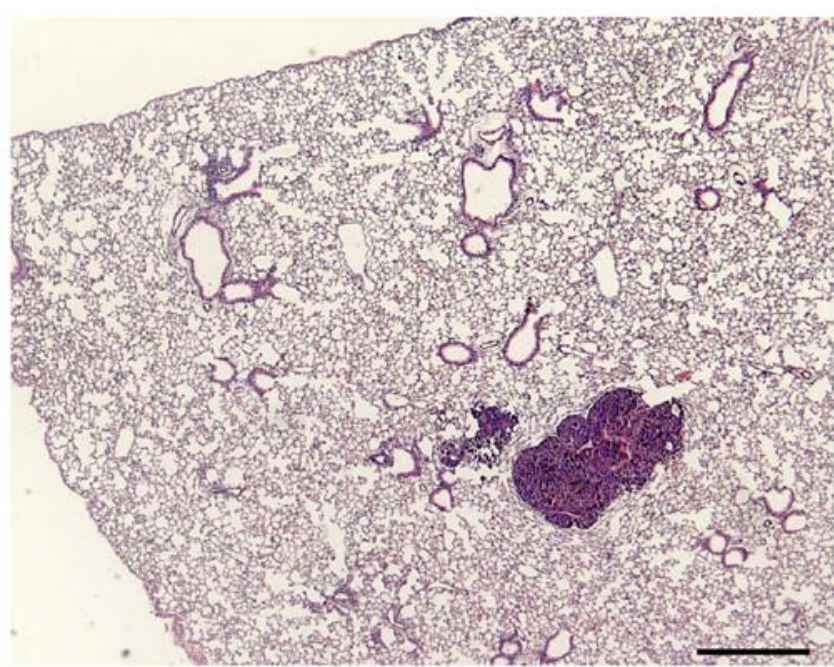

Figure 6. Photomicrograph of a histological section from the lung of a C57BL/6 mouse that was inoculated through the tail vein with B16/F10 melanoma cells and received treatment with $0.467 \mu \mathrm{g}$ E. tirucalli latex in $200 \mu 1$ saline solution. Preserved pulmonary alveoli and small-sized colonies of metastatic melanoma cells are observed. Hematoxylin and eosin staining. Bar, $500 \mu \mathrm{m}$. E. tirucalli, Euphorbia tirucalli.

of São Paulo, Brazil. Rafael Lanciani Brunetti was the recipient of a fellowship from Capes, Ministry of Education, Brazil.

\section{Funding}

The present study was supported by grants from the National Council for the Scientific and Technologic Development, CNPq, Ministry of Science, Technology, Innovation and Communications of Brazil, and the São Paulo Research Foundation, FAPESP.

\section{Availability of data and materials}

The datasets used and/or analyzed during the present study are available from the corresponding author on reasonable request. 


\section{Authors' contributions}

RLB performed the in vitro and animal studies. DPADP obtained the E. tirucalli plant, standardized the harvesting and dilution of the latex, and helped in the in vitro experiments. IIMDF, MKN, MPDG and COMSG helped in the in vitro studies with melanoma cells, including the statistical analysis. CMCM and NQH helped in the in vivo experiments. MLZD and FJHB mentored the study, supervised the students and reviewed the manuscript. All the authors have read and approved the final version of this manuscript.

\section{Ethics approval and consent to participate}

The experimental protocols were approved by the Committee on Ethics in Animal Use (CEUA) of the School of Veterinary Medicine and animal Science of the University of São Paulo (SVMAS-USP, process no. 3410250216) and the School of Medicine of the University of São Paulo (FM-USP, process no. 043/16).

\section{Patient consent for publication}

Not applicable.

\section{Competing interests}

The authors declare that they have no competing interests.

\section{References}

1. Bani S, Kaul A, Khan B, Gupta VK, Satti NK, Suri KA and Qazi GN: Anti-arthritic activity of a biopolymeric fraction from Euphorbia tirucalli. J Ethnopharmacol 110: 92-98, 2007.

2. Imai S, Sugiura M, Mizuno F, Ohigashi H, Koshimizu K, Chiba S and Osato T: African Burkitt's lymphoma: A plant, Euphorbia tirucalli, reduces Epstein-Barr virus-specific cellular immunity. Anticancer Res 14: 933-936, 1994.

3. Cataluña P and SMK Rates: The traditional use of the latex from Euphorbia tirucalli Linnaeus (Euphorbiaceae) in the treatment of cancer in South Brazil. Acta Hortic 501, 289-296, 1999.

4. Betancur-Galvis LA, Morales GE, Forero JE and Roldan J: Cytotoxic and antiviral activities of Colombian medicinal plant extracts of the Euphorbia genus. Mem Inst Oswaldo Cruz 97: 541-546, 2002

5. Valadares MC, Carrucha SG, Accorsi W and Queiroz ML: Euphorbia tirucalli L. modulates myelopoiesis and enhances the resistance of tumour-bearing mice. Int Immunopharmacol 6: 294-299, 2006
6. Agra MF, Silva KN, Basílio IJ, Freitas PF and Barbosa-Filho JM: Survey of medicinal plants used in the region Northeast of Brazil. Rev Bras Farmacogn 18: 472-508, 2008

7. Lin MW, Lin AS, Wu DC, Wang SSW, Chang FR, Wu YC, Huang YB and Huang YB: Euphol from Euphorbia tirucalli selectively inhibits human gastric cancer cell growth through the induction of ERK1/2-mediated apoptosis. Food Chem Toxicol 50: 4333-4339, 2012.

8. Mwine J, Van Damme P, Hastilestari BR and Papenbrock J: Euphorbia tirucalli L. (Euphorbiaceae) - The Miracle Tree: Current Status of Knowledge. In: African Natural Plant Products Volume II: Discoveries and Challenges in Chemistry, Health, and Nutrition ACS Symposium Series. American Chemical Society, Washington, DC, 2013.

9. Lorenzi H and Matos FJ: Euphorbia tirucalli Plantas Medicinais do Brasil: Nativas e Exóticas. Instituto Plantarum, São Paulo, pp211-212, 2002.

10. Newbold GT and Spring FS: The Euphorbia resins. Part I.Euphol The isolation of Euphol and alfa-Euphorbol from Euphorbium. J Chem Soc 249-252, 1944

11. Fürstenberger G and Hecker E: On the active principles of the Euphorbiaceae, XII. Highly unsaturated irritant diterpene esters from Euphorbia tirucalli originating from Madagascar. J Nat Prod 49: 386-397, 1986.

12. Palharini JG, Richter AC, Silva MF, Ferreira FB, Pirovani CP, Naves KS, Goulart VA, Mineo TW, Silva MJ and Santiago FM: Eutirucallin: A lectin with antitumor and antimicrobial properties. Front Cell Infect Microbiol 7: 136, 2017.

13. Santos OJ, Sauaia Filho EN, Nascimento FR, Júnior FC, Fialho EM, Santos RH, Santos RA and Serra IC: Use of raw Euphorbia tirucalli extract for inhibition of ascitic Ehrlich tumor. Rev Col Bras Cir 43: 18-21, 2016.

14. Wang L, Wang G, Yang D, Guo X, Xu Y, Feng B and Kang J: Euphol arrests breast cancer cells at the G1 phase through the modulation of cyclin D1, p21 and p27 expression. Mol Med Rep 8: 1279-1285, 2013.

15. Fidler IJ, Gersten DM and Riggs CW: Relationship of host immune status to tumor cell arrest, distribution, and survival in experimental metastasis. Cancer 40: 46-55, 1977.

16. Fukumasu H, Avanzo JL, Nagamine MK, Barbuto JA, Rao KV and Dagli ML: Paullinia cupana Mart var. sorbilis, guaraná, reduces cell proliferation and increases apoptosis of B16/F10 melanoma lung metastases in mice. Braz J Med Biol Res 41: 305-310, 2008.

17. Aherne WA and Dunnil MS: Morphometry. Edward Arnold Ltd., London, 1982.

18. Weibel ER: Stereological Methods: Practical Methods for Biological Morphometry. Academic Press, London, 1979.

19. Zips D, Thames HD and Baumann M: New anticancer agents: In vitro and in vivo evaluation. In Vivo 19: 1-7, 2005.

20. Silva VA, Rosa MN, Tansini A, Oliveira RJ, Martinho O, Lima JP, Pianowski LF and Reis RM: In vitro screening of cytotoxic activity of euphol from Euphorbia tirucalli on a large panel of human cancer-derived cell lines. Exp Ther Med 16: 557-566, 2018. 